Jurnal_ep, Vol. 9 No. 1, Maret 2019

\title{
EVALUASI DISKREPANSI TERHADAP IMPLEMENTASI PENDEKATAN SAINTIFIK PADA MUATAN PELAJARAN MATEMATIKA TEMA ORGAN TUBUH MANUSIA DAN HEWAN KELAS V SD DI KECAMATAN DENPASAR BARAT
}

\author{
Oleh \\ Luh Gede Gellyna Pravitayani, Nyoman Dantes, I Made Candiasa \\ Program Studi Penelitian dan Evaluasi Pendidikan, Program Pascasarjana \\ Universitas Pendidikan Ganesha \\ Singaraja, Indonesia
}

e-mail: gellyna.pravitayani.@undiksha.ac.id, nyoman.dantes@pasca.undiksha.ac.id, madecandiasa@undiksha.ac.id

\begin{abstract}
Abstrak
Penelitian ini bertujuan untuk mengetahui diskrepansi pendekatan saintifik terkait implementasi pendekatan saintifik pada muatan pelajaran matematika tema organ tubuh manusia dan hewan kelas V SD di Kecamatan Denpasar Barat. Penelitian ini merupakan penelitian evaluatif dengan model diskrepansi. Populasi dalam penelitian ini adalah seluruh guru kelas V SD Negeri di Kecamatan Denpasar Barat yang terdiri dari 8 gugus dan terdapat 55 sekolah. Sampel ditentukan dengan teknik Multistage Random Sampling dalam 3 tahap. Data dikumpulkan dengan menggunakan kuesioner persepsi guru, lembar observasi pembelajaran berpendekatan saintifik, dan dokumentasi untuk mengetahui hasil belajar matematika. Data dianalisis dengan menggunakan teknik analisis deskripyif kuantitatif dan analisis korelasi product moment. Hasil penelitian ini menunjukan bahwa : (1) diskrepansi yang terjadi terkait perencanaan pembelajaran berpendekatan saintifik sebesar 32,28 tergolong kategori kecil; (2) diskrepansi yang terjadi terkait pelaksanaan pembelajaran berpendekatan saintifik sebesar 32,79 tergolong kategori kecil; (3) diskrepansi yang terjadi terkait penilaian pembelajaran berpendekatan saintifik sebesar 34,74 tergolong kategori kecil; (4) diskrepansi yang terjadi terkait implementasi pembelajaran berpendekatan saintifik sebesar 33,27 tergolong kategori kecil; (5) persepsi guru tentang pendekatan saintifik sebesar 74,71 dengan kategori baik; (6) rata-rata nilai matematika tema organ tubuh manusia dan hewan sebesar 67 dengan kategori baik, dan; (7) tidak terdapat kontribusi antara kualitas pengelolaan proses pembelajaran berpendekatan saintifik dengan hasil belajar matematika tema organ tubuh manusia dan hewan kelas V SD di Kecamatan Denpasar Barat, dengan kategori korelasi sangat rendah.

Kata Kunci: evaluasi, diskrepansi, pendekatan saintifik
\end{abstract}

\begin{abstract}
This study aims to determined the magnitude of discrepancy scientific approach on the mathematics subjects of human and animal organs theme at grade $5^{\text {th }}$ elementary school in West Denpasar Sub-district. This research was evaluative research with discrepancy model. The population in this research was the grade $5^{\text {th }}$ (fifth) teachers of elementary school in West Denpasar Sub-district which cinsist of 8 clusters and 55 school. The sample were determined by Multistage Random Sampling technique in three stages. Data were collected by using teacher perception questionnaire, observation sheet of the scientific approach, and documentation to find out the results of mathematics learning. Data were analyzed by using quantitative descriptive analysis technique and product moment correlation analysis. The result of this study indicated indicated (1) the discrepancy thatoccurs related to the learning plan of scientific approaches is about 32,28 with small category; (2) discrepancy that occurs
\end{abstract}


related to implementation of science-based learning is about 32,79 with small category; (3) discrepancy related to the assessment of the scientific approach learning amouted to 34,74 in the small category; (4) the discrepancy that occured related to the implementation of science based learning approaches amouted to 33,27 to small category; (5) the teachers perception abaout the scientific approach is 74,71 with good category; (6) the average mathematical value on the theme of human and animal organs of 67 in the medium category, and; (7) there is no contribution between the quality of management learning process of scientific approach with the result of mathematics learning on the theme human and animal organs in West Denpasar Subdistric, with very low correlation categories.

Keywords: Evaluation, discrepancy, scientific approach

\section{PENDAHULUAN}

Seiring berjalannya waktu, kehidupan manusia semakin memiliki tantangan untuk mengikuti perkembangan globalisasi ini. Dengan pengaruh globalisasi seseorang akan dituntut memiliki skill cukup dan pengetahuan yang luas untuk bekal masa depan dalam memenuhi kebutuhan hidupnya. "Perkembangan ilmu pengetahuan dan teknologi sangatlah cepat, hal ini menjadikan manusia lebih tertantang dalam segala dimensi kehidupan" (Dantes, 2014). Pengetahuan yang luas dan bermakna didapat melalui pendidikan yang berkualitas pula. Pembelajaran bermaknalah yang dapat memberikan pengembangan ilmu pengetahuan. Pembelajaran bermakna itu sendiri dapat diperoleh dari pembelajaran yang berbasis student centered dan bukan lagi teacher centered. Dari pembelajaran tersebut memberikan pengalaman yang lebih bermakna bagi peserta didik dan melekat selalu dalam pikiran mereka terlebih lagi jika ilmu pengetahuan penerapannya dapat dirasakan dalam kehidupan nyata mereka.

Banyak hal yang
mempengaruhi kualitas dan
pendidikan. Hal ini terlihat dari kualitas
pendidikan di negara kita yang masih
sangat rendah, tetapi masih belum
menemukan jalan titik terang untuk
mendapatkan solusi yang baik guna
meningkatkan kualitas dan mutu
pendidikan kita.

Berbagai cara telah dilakukan untuk memperbaiki sistem pendidikan, namun apa yang dirasa belum maksimal dan masih berada ditingkat yang rendah dibandingkan dengan negara-negara maju lainnya.

"Banyak aspek yang berpengaruh dalam usaha peningkatan mutu pendidikan antara lain kurikulum pendidikan nasional, profesionalisme pendidik dan tenaga kependidikan, partisipasi peserta didik, serta peran pemerintah dan masyarakat" (Depdiknas, 2007). Salah satu upaya pemerintah yang lebih terlihat pada saat ini adalah telah mencanangkan program baru dalam kebijakan kurikulum, didalamnya terdapat berbagai pengembangan struktur kurikulum yang telah ditetapkan guna memajukan pendidikan dan kualitas output yang lebih baik.

Guru sebagai ujung tombak pelaksanaan proses pembelajaran di sekolah memiliki tugas yang cukup berat. Mereka dituntut untuk meningkatkan kompetensi dan keahliannya terkait dengan metode dan strategi pembelajaran. Sebab, sukses tidaknya proses pendidikan dalam mewujudkan siswa yang sesuai dengan stantard kompetensi lulusan, itu tergantung pada keahlian seorang guru dalam "merencanakan" proses pembelajaran di dalam kelas yang tertuang dalam Silabus dan RPP.

Namun kenyataannya guru masih kesulitan untuk melaksanakan hal tersebut, telihat dari beberapa pendapat guru yang mengatakan lebih sulit melaksanakan kurikulum 2013 dibandingkan dengan KTSP. Hal ini didapat berdasarkan hasil wawancara dengan beberapa guru yang mengajar di Kecamatan Denpasar Barat. Berbagai macam permasalahan yang dirasakan guru, selain itu guru yang terlalu pesimis 
dan tidak mau berusaha untuk melakukan perubahan menjadikan susahnya tercapai program yang dicanangkan pemerintah. Seperti, kurangnya pemahaman guru mengenai pelaksanaan kurikulum 2013 dikarenakan masih ada beberapa guru yang belum mendapatkan pelatihan, sedangkan guru yang sudah mendapatkan pelatihan belum dapat melaksanakan pembelajaran secara maksimal karena pelatihan yang hanya dilaksanakan beberapa hari dirasa belum cukup untuk melaksanakan perubahan pembelajaran yang kompleks, selain itu fasilitas yang kurang memadai dari pemerintah untuk mendukungnya proses pembelajaran, serta buku panduan siswa dan guru yang datangnya terlambat sedangkan pembelajaran sudah terlewatkan. Dari beberapa hambatan tersebut pihak sekolah selalu berusaha untuk menjalankan program yang telah dicanangkan. Dari hal-hal tersebutlah muncul kesenjangan yang terjadi terkait dengan pelaksanaan kurikulum 2013.

Berdasarkan latar belakang masalah tersebut, maka penulis akan melakukan penelitian evaluasi program mengenai tingkat kesenjangan yang terjadi antara pelaksanaan pendekatan saintifik yang sesuai dengan kurikulum dengan pelaksanaan sebenarnya dilapangan, yang berjudul "Evaluasi Diskrepansi terhadap Implementasi Pendekatan Saintifik Pada Muatan Pelajaran Matematika Tema Organ Tubuh Manusia dan Hewan Kelas V SD di Kecamatan Denpasar Barat".

Oleh karena itu tujuan yang ingin dicapai dalam penelitian ini adalah: a) Untuk mendeskripsikan diskrepansi yang terjadi terkait dengan perencanaan proses pembelajaran berpendakatan saintifik pada muatan pelajaran matematika tema Organ Tubuh Manusia dan Hewan kelas V SD di Kecamatan Denpasar Barat. b) Untuk mendeskripsikan diskrepansi yang terjadi terkait dengan proses pembelajaran berpendekatan saintifik pada muatan pelajaran matematika tema Organ Tubuh Manusia dan Hewan kelas V SD di Kecamatan Denpasar Barat. c) Untuk mendeskripsikan diskrepansi yang terjadi terkait dengan pelaksanaan penilaian penilaian pembelajaran berpendekatan saintifik pada muatan pelajaran matematika tema Organ Tubuh Manusia dan Hewan kelas V SD di Kecamatan Denpasar Barat. d) Untuk mendeskripsikan diskrepansi yang terjadi terkait implementasi pendekatan saintifik pada muatan pelajaran matematika tema Organ Tubuh Manusia dan Hewan kelas V SD di Kecamatan Denpasar Barat. e) Untuk memperoleh diskripsi tentang persepsi guru tentang implementasi pendekatan saintifik pada mata pelajaraan matematika tema Organ Tubuh Manusia dan Hewan kelas V SD di Kecamatan Denpasar Barat. f) Untuk mengetahui bagaimanakah hasil belajar matematika tema Organ Tubuh Manusia dan Hewan kelas V SD di Kecamatan Denpasar Barat terkait implementasi pendekatan saintifik. g) Untuk mengetahui seberapa besar kontribusi kualitas pengelolaan proses pembelajaran berpendekatan saintifik terhadap hasil belajar matematika tema Organ Tubuh Manusia dan Hewan kelas V SD di Kecamatan Denpasar Barat.

\section{METODE}

Penelitian ini termasuk penelitian evaluasi program jenis penelitian kebijakan. Program yang di evaluasi adalah Pendekatan Saintifik pada Kurikulum 2013 di sekolah dasar. Model evaluasi program yang digunakan adalah model diskrepansi (The Discrepancy Evaluation Model). Model diskrepansi ini dikembangkan oleh Malcolm Provus (1971) yang percaya bahwa evaluasi merupakan suatu seni (art) melukiskan ketimpangan antara standar kerja dengan kinerja yang terjadi (Wirawan, 2012: 106). Provus menekankan menekankan pada kesenjangan yang sebetulnya merupakan persyaratan umum bagi semua kegiatan evaluasi, yaitu mengukur adanya perbedaan antara yang seharusnya dicapai dengan yang sudah riil dicapai. Hasil evaluasi digunakan sebagai alat pengawasan dan alat bantu pengembangan program. Model ini dapat digunakan untuk mengevaluasi semua jenis program dan yang menjadi dasar adalah menilai kesenjangan. 
Penelitian ini berorientasi pada tingkat deskriptif. Tingkat deskriptif yang dimaksud yaitu mencari informasi mengenai kualitas pelaksanaan suatu kebijakan, menggambarkan fenomena yang terjadi terkait implementasi pendekatan saintifik dalam pembelajaran dengan menganalisis kesenjangan (diskrepansi) antara unjuk kerja tingkah laku guru dalam mengimplementasikan pendekatan saintifik dan standar tujuan yang telah ditetapkan yaitu Permendikbud No. 22 Tahun 2016.

Populasi dalam penelitian ini adalah seluruh guru kelas V SD Negeri di Kecamatan Denpasar Barat. Sekolah Dasar Negeri di Kecamatan Denpasar Barat terdiri atas 55 sekolah yang terbagi dalam 8 gugus. Teknik pengambilan sampel yang digunakan pada penelitian ini adalah Multistage Random Sampling. Multy stage sampling adalah pengambilan sampel secara bertahap, dari elemen polpulasi yang lebih besar (yang karakteristiknya sudah pasti) ke elemen populasi yang lebih kecil dan begitu seterusnya (Dantes, 2012:44). Untuk memperoleh sampel yang dapat mewakili populasi, sampling dilakukan dalam 3 tahap. Tahap pertama, dilakukan sampling terhadap gugus di Kecamatan Denpasar Barat (subpopulasi). Tahap kedua, dari gugus-gugus terpilih kemudian ditentukan sekolah-sekolah yang menjadi sampel. Tahap ketiga, penentuan sampel dari masing-masing sekolah yang terpilih. Sehingga, sampel dalam penelitian ini adalah 17 orang guru kelas $\mathrm{V}$.

Penelitian ini melibatkan empat variabel, yaitu variabel pembelajaran berpendekatan saintifik (perencanaan, pelaksanaan, dan penilaian pembelajaran), persepsi guru tentang pendekatan saintifik, hasil belajar Matematika siswa, dan kualitas pengelolaan pembelajaran berpendekatan saintifik.

Untuk memperoleh data dalam suatu penelitian diperlukan metode pengumpulan data. Dalam penelitian ini metode yang digunakan untuk mengumpulkan data antara lain: (1) metode kuesioner digunakan untuk mengambil data penelitian terkait persepsi guru tentang pendekatan saintifik, (2) metode observasi digunakan untuk mengambil data terkait perencanaan pembelajaran berpendekatan saintifik, pelaksanaan pembelajaran berpendekatan saintifik, dan penilaian pembelajaran berpendekatan saintifik, serta (3) studi dokumentasi digunakan untuk mengambil data terkait hasil belajar Matematika siswa kelas $\mathrm{V}$ pada tema organ tubuh manusia dan hewan.

Instrumen yang digunakan dalam penelitian ini adalah instrumen observasi format IPKG (Instrumen Penilaian Kemampuan Guru) yang disusun berdasarkan acuan kriteria pembelajaran berpendekatan saintifik yang terdapat dalam Permendikbud No. 22 Tahun 2016 dan instrumen kuesioner persepsi guru tentang pendekatan saintifik. Sebelum instrumen digunakan maka perlu dilakukan validasi instrumen. Untuk instrumen observasi format IPKG dilakukan uji validitas isi menggunakan rumus Gregory (uji dua pakar). Untuk instrumen kuesioner tentang pendekatan saintifik dilakukan uji validitas isi menggunakan rumus Gregory (uji dua pakar), uji internal konsistensi butir menggunakan korelasi Pearson Product Moment, dan uji reliabilitas menggunakan rumus Alpha Cronbach.

Data yang diperoleh dalam penelitian ini dianalisis menggunakan teknik analisis deskriptif kuantitatif dan analisis korelasi product moment. Metode analisis statistik deskriptif adalah cara pengolahan data yang dilakukan dengan penghitungan persentase permunculan suatu fenomena atau respons, dan pencatatan perkembangan maupun dokumen (Dantes, 2012:157). Analisis deskriptif kuantitatif dalam penelitian ini digunakan untuk menggambarkan data pembelajaran berpendekatan saintifik (perencanaan, pelaksanaan, dan penilaian pembelajaran), persepsi guru, dan hasil belajar siswa. Dalam metode deskriptif kuantitatif ini data hasil penelitian diubah ke dalam data persentil kemudian dikonversikan ke dalam tabel Klasifikasi Kemampuan Guru (adaptasi Guilford) yang menggunakan skala lima sebagai berikut. 
Jurnal_ep, Vol. 9 No. 1, Maret 2019

Tabel 1. Klasifikasi Kemampuan Guru

\begin{tabular}{ccc}
\hline No & $\begin{array}{c}\text { Kriteria } \\
\text { Penguasaan (\%) }\end{array}$ & Keterangan \\
\hline 1 & $81-100$ & Sangat Baik \\
2 & $61-80$ & Baik \\
3 & $41-60$ & Cukup Baik \\
4 & $21-40$ & Kurang Baik \\
5 & $0-20$ & Sangat Kurang \\
& & Baik \\
\hline
\end{tabular}

Adaptasi Guilford (Candiasa, 2010:80)

hasil $\begin{gathered}\text { Selanjutnya, untuk analisis data } \\ \text { observasi }\end{gathered}$ pelaksanaan, dan penilaian pembelajaran berpendekatan saintifik yang sudah diubah ke dalam data bentuk persentil dicari tingkat kesenjangan dengan standar acuan Permendikbud. Tingkat kesenjangan yang diperoleh, kemudian dikategorikan pada tabel acuan kriteria diskrepansi. Kriteria tersebut merupakan adaptasi dari kriteria Guilford yang rentangannya diubah dalam bentuk persentil.

Tabel 2. Acuan Kriteria Diskrepansi

\begin{tabular}{ccc}
\hline No & $\begin{array}{c}\text { Kriteria } \\
\text { Diskrepansi }\end{array}$ & Keterangan \\
\hline 1 & $0-20$ & Sangat Kecil \\
2 & $21-40$ & Kecil \\
3 & $41-60$ & Sedang \\
4 & $61-80$ & Lebar \\
5 & $81-100$ & Sangat Lebar \\
\hline
\end{tabular}

Adaptasi Guilford (Candiasa, 2010:80)

Analisis korelasi product moment digunakan untuk mencari hubungan dan membuktikan hipotesis hubungan dua variabel bila data kedua variabel berbentuk interval atau rasio, dan sumber data dari dua variabel lebih tersebut adalah sama (Sugiyono, 2013:228). Hipotesis yang dibuktikan dalam penelitian ini adalah kontribusi kualitas pengelolaan pembelajaran berpendekatan saintifik terhadap hasil belajar Matematika tema organ tubuh manusia dan hewan kelas $\mathrm{V}$ SD di Kecamatan Denpasar Barat. Sebelum melakukan analisis korelasi product moment, dilakukan uji prasyarat analisis diantaranya uji normalitas data dan uji linieritas data. Untuk mengetahui apakah terdapat hubungan yang signifikan atau tidak, $r_{x y}$ perlu dikorelasikan dengan $r$ tabel dengan $\mathrm{dk}=\mathrm{n}-2$. Adapun kriteria pengujian sebagai berikut. Jika $r_{x y}>r$ tabel maka $\mathrm{H}_{0}$ ditolak dan $\mathrm{H}_{\mathrm{a}}$ diterima, sebaliknya Jika $r_{x y}<r$ tabel maka $H_{0}$ diterima dan Ha ditolak. Selanjutnya untuk mengetahui seberapa besar kontribusi kualitas pengelolaan pembelajaran berpendekatan saintifik terhadap hasil belajar Matematika dapat ditentukan dengan koefisien determinasi $\left(r^{2} x y\right)$ yang merupakan kuadrat dari koefisien korelasi $r_{x y}$. Untuk memberikan penafsiran tentang keeratan korelasi antara variabel $X$ dan $Y$ maka korelasinya dapat dikelompokan sebagai berikut. 
Tabel 3. Kategori Korelasi

\begin{tabular}{cc}
\hline Interval & Kategori \\
\hline $0,00<r \leq 0,20$ & Korelasi sangat rendah \\
$0,20<r \leq 0,40$ & Korelasi rendah \\
$0,40<r \leq 0,60$ & Korelasi sedang \\
$0,60<r \leq 0,80$ & Korelasi tinggi \\
$0,80<r \leq 1,00$ & Korelasi sangat tinggi \\
\hline
\end{tabular}

Guilford (dalam Candiasa, 2010:80)

\section{HASIL DAN PEMBAHASAN} mengenai implementas pendekatan saintifik pada muatan pelajaran Matematikia tema organ tubuh manusia dan hewan kelas V SD di Kecamatan Denpasar Barat tahun ajaran 2016/2017 dengan standar acuan Permendikbud No. 22 Tahun 2016 pada Kurikulum 2013, diperoleh hasil sebagai berikut.

Hasil analisis menunjukkan perolehan skor rata-rata kemampuan guru dalam perencanaan pembelajaran berpendekatan saintifik adalah 67,04 dan termasuk kategori baik. Setelah dibandingkan skor yang diperoleh dari setiap dimensi pada variabel perencanaan pembelajaran dengan skor ideal, diperoleh beda sebesar 32,96 dengan kategori diskrepansi kecil.

Pada pelaksanaan pembelajaran berpendekatan saintifik diperoleh skor rata-rata kemampuan guru adalah 67,21 dan termasuk kategori cukup baik. Setelah dibandingkan skor yang diperoleh dari setiap dimensi pada variabel pelaksanaan pembelajaran dengan skor ideal, diperoleh beda sebesar 32,79 dengan kategori diskrepansi kecil.

Pada penilaian pembelajaran berpendekatan saintifik diperoleh skor rata-rata kemampuan guru adalah 65,26 dan termasuk kategori baik. Setelah dibandingkan skor yang diperoleh dari setiap dimensi pada variabel penilaian pembelajaran dengan skor ideal, diperoleh beda sebesar 34,74 dengan kategori diskrepansi kecil.

Secara keseluruhan perolehan skor rata-rata implementasi pendekatan saintifik adalah 66,73 dan termasuk kategori baik. Besar beda antara skor ideal dan rerata skor di lapangan terkait implementasi pendekatan saintifik dalam pembelajaran sebesar 33,27 dengan kategori diskrepansi kecil. Hasil analisis diskrepansi implementasi pendekatan saintifik (perencanaan, pelaksanaan, dan penilaian pembelajaran) disajikan pada tabel berikut.

Tabel 4. Hasil Analisis Diskrepansi Implementasi Pendekatan Saintifik

\begin{tabular}{ccccc}
\hline Variabel & Standar & Skor & Beda & $\begin{array}{c}\text { Kategori } \\
\text { Diskrepansi }\end{array}$ \\
\hline $\begin{array}{l}\text { Perencanaan } \\
\text { pembelajaran }\end{array}$ & 100 & 67,04 & 32,96 & Kecil \\
$\begin{array}{l}\text { Pelaksanaan } \\
\text { pembelajaran }\end{array}$ & 100 & 67,21 & 32,79 & Kecil \\
$\begin{array}{l}\text { Penilaian } \\
\text { pembelajaran }\end{array}$ & 100 & 65,26 & 34,74 & Kecil \\
\hline \multicolumn{1}{c}{ Total } & $\mathbf{1 0 0}$ & $\mathbf{6 6 , 7 3}$ & $\mathbf{3 3 , 2 7}$ & Kecil \\
\hline
\end{tabular}


Hasil analisis persepsi guru tentang implementasi pendekatan saintifik sebesar 74,71 dan termasuk kategori baik. Ratarata perolehan nilai pengetahuan Matematika tema organ tubuh manusia dan hewan dari 17 kelas V SD di Kecamatan Denpasar Barat adalah 67 dan termasuk kategori baik.

Hasil uji prasyarat analisis, yaitu, untuk uji normalitas data digunakan uji Liliefors. Data yang diuji normalitas datanya adalah data kualitas pengelolaan pembelajaran berpendekatan saintifik dan data hasil belajar Matematika tema organ tubuh manusia dan hewan kelas V SD di Kecamatan Denpasar Barat. Dari hasil uji normalitas data kualitas pengelolaan pembelajaran berpendekatan saintifik

Dari hasil perhitungan, didapatkan $\mathrm{F}$ hitung (tuna cocok) $=-0,091$, sedangkan $F$ tabel untuk dk 11:4 (pembilang $=11$ dan penyebut $=4$ ) untuk taraf signifikansi $5 \%=$ 5,94. Ini berarti harga $F$ hitung (tuna cocok) $=-0,091<\mathrm{F}$ tabel $=5,94$, sehingga $\mathrm{H}_{\mathrm{o}}$ diterima dan $\mathrm{F}$ tuna cocok adalah non signifikan. Dengan demikian hubungan antara kualitas proses pembelajaran berpendekatan saintifik dan hasil belajar matematika adalah linear.

Dari hasil perhitungan, didapatkan $F$ hitung (regresi) $=85,659$ sedangkan $F$ tabel untuk dk 1:4 (pembilang $=1$ dan penyebut $=4$ ) untuk taraf signifikansi $5 \%=$ 7,71 . Ini berarti harga $F$ regresi $=85,659>$ harga $F$ tabel $=7,71$, sehingga hipotesis alternatif diterima dan harga $F$ regresi adalah signifikan. Dengan demikian terdapat hubungan fungsional yang signifikan antara kualitas proses pembelajaran berpendekatan saintifik dan hasil belajar matematika.

Setelah dilakukan uji prasyarat analisis, dilakukan korelasi product moment. Dari analisis korelasi product moment diperoleh koefisien korelasi $r_{x y}=$ 0,0080 . Berdasarkan data sebanyak 15 dengan taraf signifikansi $5 \%$ maka ditemukan $r_{\text {tabel }}=0,482$. Dengan demikian $r_{\text {hitung }}>r_{\text {tabel }}$ sehingga $\mathrm{H}_{0}$ diterima dan hasil tidak signifikan. Sehingga hipotesis yang menyatakan bahwa "Tidak terdapat kontribusi kualitas pengelolaan proses pembelajaran berpendekatan saintifik terhadap hasil belajar Matematika tema organ tubuh manusia dan hewan kelas $\mathrm{V}$ SD di Kecamatan Denpasar Barat" diterima.

Berdasarkan hasil analisis tersebut, dapat diketahui bahwa terjadi diskrepansi pada variabel perencanaan pembelajaran berpendekatan saintifik. Komponen dalam perencanaan pembelajaran berpendekatan saintifik yang masih kurang terlihat yaitu pada penggorganisasian kegiatan belajar, masih ada guru yang belum mengaitkan materi ajar dengan kehidupan nyata.

Pada variabel pelaksanaan pembelajaran berpendekatan saintifik juga terjadi diskrepansi. Komponen dalam pelaksanaan pembelajaran berpendekatan saintifik yang masih kurang terlihat, yaitu guru belum menggunakan sumber dan media pembelajaran yang mendukung pembelajaran secara ilmiah, dikarenakan minimnya media pembelajaran yang tersedia di sekolah. Dalam implementasi $6 \mathrm{M}$ pengalaman belajar pendekatan saintifik, untuk kegiatan Menanya, Mencoba, dan Mencipta masih jarang terlihat, yang disebabkan kurangnya alokasi waktu yang disediakan untuk melakukan kegiatan pembelajaran dan jumlah siswa dalam satu rombongan belajar melebihi jumlah maksimun ketentuan standar proses yaitu melebihi 28 orang.

Pada variabel penilaian pembelajaran berpendekatan saintifik juga terjadi diskrepansi. Komponen dalam penilaian pembelajaran berpendekatan saintifik yang masih kurang terlihat, yaitu masih ada beberapa guru yang belum melakukan penilaian autentik, rubrik yang disiapkan diperencanaan belum dilaksanakan, pelaporan guru yang dilkukan sudah menggunakan aplikasi.. Kendala yang sering dihadapi guru dalam penilaian pembelajaran tersebut didukung oleh penelitian Marhaeni dan Artini (2015) yang mengungkapkan bahwa keterbatasan akan ketersediaan tipe dan jenis asesmen yang siap pakai dan berkualitas tidak tersedia sehingga membuat para guru harus mencari asesmen yang sesuai dan bahkan 
sebagian besar akhirnya tidak menerapkan penggunaan asesmen tersebut dikarenakan mengalami kesulitan untuk menemukan contoh asesmen yang sesuai atau baik. Meskipun mereka bisa menemukan beberapa instrumen asesmen yang sudah dibuat orang, mereka mengalami masalah dalam memodifikasi asesmen tersebut agar dapat digunakan di sekolah yang mereka ajar.

Secara keseluruhan, hasil analisis tingkat kemampuan guru kelas $\mathrm{V}$ di Kecamatan Denpasar Barat dalam implementasi pendekatan saintifik pada Kurikulum 2013 menunjukkan kemampuan yang baik. Dan terjadi diskrepansi dalam kategori kecil. Hal ini menunjukkan bahwa guru sudah melaksanakan perencanaan, pelaksanaan, dan penilaian pembelajaran berpendekatan saintifik dengan baik.

Persepsi guru tentang implementasi pendekatan saintifik pada muatan pelajaran Matematika tema organ tubuh manusia dan hewan kelas V SD di Kecamatan Denpasar Barat termasuk kategori baik. Hal ini menunjukkan bahwa guru telah memiliki pengetahuan mengenai hakikat dan langkah-langkah pembelajaran berpendekatan saintifik yang baik. Persepsi yang sudah dimiliki guru tentang implementasi pendekatan saintifik ini akan berpengaruh pada kemampuan guru dalam merancang perencanaan pembelajaran, melaksanakan proses pembelajaran menggunakan pendekatan saintifik, dan menyusun penilaian pembelajaran sesuai asesmen autentik yang tentunya akan berpengaruh juga pada hasil belajar siswa.

Pencapaian hasil belajar Matematika siswa yang menggunakan pendekatan saintifik pada tema organ tubuh manusia dan hewan kelas V SD di Kecamatan Denpasar Barat termasuk kategori baik. Hal ini menunjukkan bahwa implementasi pendekatan saintifik di Kecamatan Denpasar Barat telah dilaksanakan dengan baik. Sejalan dengan hasil penelitian Artadi (2016) yang menyatakan bahwa pendekatan saintifik berpengaruh terhadap prestasi belajar siswa.
Hasil analisis menunjukkan bahwa kualitas pengelolaan proses pembelajaran berpendekatan saintifik berkontribusi terhadap hasil belajar Matematika. Dengan kata lain terdapat pengaruh kualitas pengelolaan proses pembelajaran berpendekatan saintifik terhadap hasil belajar Matematika tema organ tubuh manusia dan hewan kelas V SD di Kecamatan Denpasar Barat. Kontribusi kualitas pengelolaan proses pembelajaran berpendekatan saintifik terhadap hasil belajar Matematika termasuk dalam kategori rendah. Namun kontribusi yang diperoleh bersifat negatif.

Hal ini disebabkan oleh beberapa faktor, seperti 1) pemilihan soal yang masih belum sesuai dengan pendekatan saintifik, dimana soal yang digunakan masih berupa tes pilihan ganda, isian singkat, yang hanya sebuah hafalan saja. 2) persepsi yang dimiliki guru tidak sesuai dengan pelaksanaannya, beberapa guru memliki persepsi dan pengetahuan yang baik namun dalam pelaksanaanya, kemampuan tersebut susah untuk diterapkan. 3) perencanaan penilaian yang dirancang tidak sesuai dengan penilaian yang dilakukan atau tidak berpedoman pada rubrik.

\section{PENUTUP}

Berdasarkan analisis dan pembahasan yang telah diuraikan, kesimpulan yang dapat diambil adalah sebagai berikut.

Diskrepansi yang terjadi terkait perencanaan pembelajaran berpendekatan saintifik pada muatan pelajaran Matematika tema organ tubuh manusia dan hewan kelas V SD di Kecamatan Denpasar Barat termasuk kategori diskrepansi kecil. Diskrepansi yang terjadi terkait pelaksanaan pembelajaran berpendekatan saintifik pada muatan pelajaran Matematika tema organ tubuh manusia dan hewan kelas $\mathrm{V}$ SD di Kecamatan Denpasar Barat termasuk kategori diskrepansi sedang. Diskrepansi yang terjadi terkait penilaian pembelajaran berpendekatan saintifik pada muatan pelajaran Matematika tema organ tubuh manusia dan hewan kelas $\mathrm{V}$ SD di Kecamatan Denpasar Barat 
termasuk kategori diskrepansi kecil. Diskrepansi yang terjadi terkait implementasi pendekatan saintifik pada muatan pelajaran Matematika tema organ tubuh manusia dan hewan kelas V SD di Kecamatan Denpasar Barat termasuk kategori diskrepansi kecil.

Persepsi guru tentang implementasi pendekatan saintifik pada muatan pelajaran Matematika tema organ tubuh manusia dan hewan kelas V SD di Kecamatan Denpasar Barat termasuk kategori baik. Pencapaian hasil belajar Matematika dengan implementasi pendekatan saintifik pada tema organ tubuh manusia dan hewan dari 17 kelas $\mathrm{V}$ SD Negeri di kecamatan Denpasar Barat, termasuk kategori baik. Kontribusi kualitas pengelolaan proses pembelajaran berpendekatan saintifik terhadap hasil belajar Matematika pada tema organ tubuh manusia dan hewan kelas V SD Negeri di Kecamatan Denpasar Barat adalah tidak signifikan dengan kategori korelasi sangat rendah.

Beberapa saran yang dikemukakan sehubungan dengan hasil yang diperoleh dalam penelitian ini adalah sebagai berikut. Guru selaku pendidik hendaknya selalu bersikap profesional dan siap untuk mengimplementasikan pendekatan saintifik sesuai tuntutan standar proses. Oleh karena itu, disarankan kepada Pendidik hendaknya selalu siap terhadap perubahan yang ada dan meningkatkan kemampuan dalam mengimplementasikannya dalam pembelajaran sehari-hari. Pemerintah hendaknya selalu melaksanakan work shop, seminar guna meningkatkan pemahaman para pendidik. Kepala satuan pendidikan dan pengawas hendaknya rutin melaksanakan pengawasan terhadap proses pembelajaran dan kelengkapan administrasi guru agar selalu dapat dibenahi

\section{DAFTAR RUJUKAN}

Arikunto, Suharsimi dan Cepi Sarifuddin Abdul Jabar. 2010. Evaluasi Program Pendidikan. Jakarta: Bumi Aksara.

Aprillia, Eka. 2014. "Implementasi Pendekatan Saintifik dalam
Kurikulum 2013 pada

Pembelajaran Sejarah". Indonesian Journal of History Education. Vol.3, No.1.

Artadi, Anik. "Pengaruh Pendekatan Saintifik dengan Setting Model Pembelajaran Berbasis Masalah Terhadap Sikap IImiah dan Prestasi Belajar IPA Pada Siswa Kelas V Sekolah Dasar di Gugus Mayor Metra Denpasar". E-Journal Program Pascasarjana Universitas Pendidikan Ganesha. Vol 6. No. 1

Dantes, Nyoman. 2012. Metode Penelitian. Yogyakarta: ANDI.

Darmadi, Hamid. 2011. Motode Penelitian Pendidikan. Bandung: Alfabeta.

Kosasih, E. 2014. Strategi Belajar dan Pembelajaran Implementasi Kurikulum 2013. Bandung: Yrama Widya.

Koyan, I Wayan. 2011. Asesmen dalam Pendidikan. Singaraja: Undiksha Press

Marhaeni, A.A.I.N. dan L. P. Artini. 2015. "Asesmen Autentik dan Pendidikan Bermakna: Implementasi Kurikulum 2013". Jurnal

Pendidikan Indonesia Program Pascasarjana Universitas Pendidikan Ganesha. Volume 4 Nomor 1 Tahun 2015.

Menteri Pendidikan dan Kebudayaan Republik Indonesia. 2014. Peraturan Menteri Pendidikan dan Kebudayaan Republik Indonesia Nomor 160 Tahun 2014 tentang Pemberlakuan Kurikulum Tahun 2006 dan Kurikulum 2013. Jakarta: Mendikbud RI.

2016. Peraturan Menteri Pendidikan dan Kebudayaan Republik Indonesia Nomor 22 Tahun 2016 tentang Standar Proses Pendidikan dan Menengah. Jakarta: Mendikbud RI.

Pusat Penelitian dan Pengembangan Kebudayaan. "Evaluasi

Pendampingan Kurikulum 2013". Tersedia pada http://litbang.kemdikbud.go.id/ pengumuman/ArtikelEvaluasi\%20Pendampingan \%2 
Jurnal_ep, Vol. 9 No. 1, Maret 2019

OK-13-Puslitbangbud.pdf .

(diakses 28 September 2016).

Sugiyono. 2013. Metode Penelitian Pendidikan Pendekatan Kuantitatif, Kualitatif, dan R\&D. Bandung: Alfabeta.

Wirawan. 2012. Evaluasi: Teori, Model, Standar, Aplikasi, dan Profesi. Jakarta: Rajawali Pers. 